International Journal of Advanced Academic Research (Arts, Humanities and Education) | ISSN: 2488-9849

Vol. 6, Issue 11 (November, 2020) |www.ijaar.org

Journal DOI: 10.46654/ij.24889849

Article DOI: 10.46654/ij.24889849.a61128

\title{
COVID-19 PANDEMIC: AN OUTLINE OF DIGITAL LEARNING TOOLS FOR CREATING TEACHING AND LEARNING CONTENTS
}

\author{
Saleh Musa ${ }^{1}$ \\ musaa099@gmail.com, +2348026203662 \\ Abubakar Sadiq Abdullahi ${ }^{2}$ \\ abubakarsadeeqk@gmail.com, +2348034593954 \\ Hirhyel James Audu ${ }^{3}$ \\ hiri4real7@gmail.com, +2348032545307
}

$\&$

Umar Usman Babagana 4

umargujba86@gmail.com, +2348038577860

${ }^{1,2,3,4}$ Department of Education, Faculty of Arts and Education, Yobe State University, Damaturu

\begin{abstract}
There is currently little or no literature on COVID-19 in relation to educational studies especially in the area of continuous teaching and learning activities. The only literature available is directly related to medical studies. This is not because education is not directly affected by the effect of the COVID-19 pandemic but rather because studies in education rarely incorporate effects of disease on the effective provision of education to learners across the globe. The paper focused on the digital learning tools for creating teaching and learning contents at COVID-19 pandemic lockdown. The prime target of the researchers is to outlinethe digital learning tools as it is useful for creating teaching and learning contents for teachers at all level of education. There are many free and paid online digital learning tools available for creating teaching and learning content, such tools include: schoology; Google classroom; Edmodo; Moddle; Grockit; ePals and a lot but just to mention but few. The aforementioned tools were free for some extent, but teachers/tutors and students have to use internet for using these tools for long teaching and learning purpose. Some of the benefits of digital learning tools include the following; to reduce time and cost, issue of any pandemic or lockdown and maintaining social distance to minimize the spread of the disease more especially during pandemic. The paper therefore suggested that there is need for insights regarding the use of digital learning tools and teachers/tutors and students alike should consider digital learning tools for creating and continuous teaching and learning activities. The paper also recommended among others that educational stakeholders in Nigeria should provide training for teachers on how to use various digital learning tools in creating teaching and learning contents.
\end{abstract}

Keywords: COVID-19 Pandemic, Digital Learning tools, Teaching and Learning contents. 


\section{INTRODUCTION}

In December 2019, a virus of uncertain origin (coronavirus-19)had been identified in Hubei Province China called Wuhan which was first confirmed by China's World Health Organization (WHO) State Offices.The Novel coronavirus-2019 (2019-nCoV or COVID-19) is by far the most dangerous coronavirus ever identified for the third time in the three decades capable of infecting not only the animals but also the humans all over the world. Nearly over1,163,434 deaths have been recorded as a result of 2019-nCoV outbreak worldwide. The pandemicity of 2019-nCoVhas dramatically surpassed severe acute respiratory syndrome coronavirus (SARS-CoV) and Middle East respiratory syndrome coronavirus (MERS-CoV) that were discovered so far in 2003 and 2012 respectively. Thus, the WHO has declared the 2019$\mathrm{nCoV}$ as Public Health Emergency of international concern on 30 January 2020 and pandemic on $11 \mathrm{March}(\mathrm{WHO}, 2020)$ and thus affecting certainly every sector of human life including Education.Currently, over 120 countries including Nigeria were reported to have more than 43,766,712 confirmed cases and 1,163,459 deaths as a result of 2019-nCoV outbreakas of 3:58pm CET, 28 October 2020. The WHO is functioning around the clock, day and night to interpret evidence, give guidance, organize with collaborators, and expand resources and handles teams of specialists to minimize the spread of the virus.

Similarly, National health specialists including state authorities are undertaking multiple measures, such as working from home, social distancing, quarantining in case of symptoms; improving health institutions to manage the infection; and request everyone to stay at home (Bedford, Enria, Giesecke, Heymann, Ihekweazu, Kobinger \& Ungchusak, 2020). Across several nations, measures to limit the spread of the 2019-nCoV between older and adolescent population have contributed to the extensive closing of schools and other educational establishments(Krienger, 2020; Linney, 2020). Since around March 25, nearly over one hundred and fifty countries had temporarily closed schools and establishments (Muhammad, Amiya, Shafiqul \& Ikram, 2020).

The 2019-nCoV pandemic has caused the largest disruption of education in the history of the world, having already had a near universal impact on learners and teachers around the world, from pre-primary to secondary schools, technical and vocational education and training (TVET) institutions, universities, adult learning, and skills development establishments and bymid of $2020,94 \%$ of learners worldwide were affected by the $2019-\mathrm{nCoV}$ pandemic, representing 1.58 billion children and youth, from pre-primary to higher education in 200 countries (United Nation, 2020).Despitethis great challenges presented by 2019-nCoV, the situation has also offered the opportunity to rethink the overall purpose, role, content and delivery of education in the long term, and prepare education systems to deal with current and future crises through comprehensive and inter-sectorial approaches and by tapping into collective experience and practices from around the world (UNESCO, 2020; Kim, 2020). On similar vein, Enoidem, Aniedi and Comfort (2020) assert that 2019-nCoV pandemic has brought about a drastic change in classroom and it is best for education sector to think about newer teaching and learning techniques based on digital learning tools and technologies.They further explained that the inclusion of digital learning in the classroom can vary from simply using tablets instead of paper to using elaborate software programs and equipment. A digital learning strategy may include any of or a combination of any of the Adaptive learning; Badging and Gamification; Blended 
Journal DOI: 10.46654/ij.24889849

learning; Classroom technologies; E-textbooks; Online learning (or e-learning); Open educational resources (OER); Technology-enhance teaching and learning; Visual reality and Augmented reality.

Moreover, before the 2019-nCoV pandemic, the world was already facing formidable challenges in fulfilling the promise of education as a basic fundamental human right. "Despite the near universal enrolment at schools in most countries, an extraordinary number of children more than 250 million were out of school, and nearly 800 million adults were illiterate" (United Nation, 2020). The 2019-nCoV pandemic has interrupted conventional schooling with nationwide school closures in most countries of the world. While the educational communities in the developed nations have made concerted efforts to maintain learning continuity during this period of pandemic, children and students have had to rely more on their own resources to continue learning remotely through the internet, television or radio. Teachers also had to adapt to new pedagogical concepts and modes of delivery of teaching, for which they may not have been trained.

The 2019-nCoV pandemic has also had a severe impact on education as schoolswere shut downand countries closed down their borders in response to the lockdown measures. Althoughin developed countries using digital learning tools were alreadyreplaced face-to-face lectures with e-learning, therefore, the effects of the pandemic was minimal. More succinctly, the 2019-nCoV pandemichas raises questions about the value offered by education sector which includes networking and social opportunities as well as educational contentto remain relevant, reinvent the learning environments so that digitalization expands and complements student-teacher and other relationships(Andreas, 2020).As a result of the pandemic, digital learning is now on the forefront in replacing traditional education methods whereby the teachers and students interact in the classroom and have physical contact with each other (Enoidem, et al., 2020).

Digital learning tools refer to any program, application package or technology that can be assessed through the use of internet connection and enhance teacher's ability to present information and a leaner's ability to access that information (Jennifer, 2020).Digital learning is any type of learning that is accompanied by technology or by instructional practice that makes effective use of technology. It encompasses the application of a wide spectrum of practice which includes banded and visual learning.Digital learning is sometimes confused with online learning or e-learning, digital learning encompasses the aforementioned concept (Wikipedia, 2020). Digital learning is learning facilitated by technology that gives students some element of control over time, path, and or place. Since digital learning is far more interactive and memorable than voluminous textbooks or one side lectures, it provides better context, a greater sense of perspective and more engaging activities than traditional education method.

\section{Digital LearningTools for Teachers to Create Teaching and Learning Contents}

For teachers to successfully change from traditional classroom toe-teaching/learning environment, the following are compiled list of some of the technology tools to create digital learning contents to include some that are becoming increasingly popular and widely used that should be part of any teachertechnology tools arsenal this year whether for their own personal use or as education aids in the classroom, however, certain tools that need to be put in place 
which use the power of social media to help teacher and students to get connected include but not limited to:

1. Edmodo: with Edmodo teachers and students can send messages, share class materials, and make learning accessible anywhere, save time by bringing all classroom tools together.Teachers and students can take advantage of this great technology tool, as it offers a Facebook-like environment where classes can connect online (Usman \& Dahiru, 2016). It allows members from different classes to share instructional content through online discussion on topical issues. To register on Edmodo for the first time, one needs to do the following:

1. Go to $\underline{w w w . e d m o d o . c o m}$ and click sign up

2. Select the top panel that reads Teacher Account

3. Select your Country

4. You also have the option of signing up with a Google or Microsoft or Apple account

5. Enter your name

6. After you have filled in these, you will be brought to your home page

To set-up Edmodo Classroom, the teacher has to follow the following:

1. To set-up the Edmodo classes, the teachers has plenty of ways to set up their schedule on Edmodo either by period which has to do with each class for each period you teach, by subject i.e. for each subject you teach and main class with small groups.

2. Invite your students to join your classroom by sharing your class code, or send email invitation

3. Now that your classes are set up and students have joined, the teacher can start conversation, post updates, activities and resources.

2. Google Class:teachers can use Google class to connect classes remotely, communicate and stay organized. It is a free web service developed by Google for schools that aim to simplify creating, distributing and grading assignments. Google classroom incorporates docs, sheets, slides, gmail and calendar into a cohesive platform to manage student and teacher communication (Enoidem, et al., 2020). While using Google classroom students can be invited to join a class through a private code, or automatically selected from a school domain. Teachers can create, distribute and mark assignments all within the Google ecosystem. Moreover, teachers, parent/guardian, students, and administrator can use Google classroom to assess the following features as summarized below: 
Journal DOI: 10.46654/ij.24889849

Article DOI: 10.46654/ij.24889849.a61128

\begin{tabular}{|c|c|}
\hline User & What you can do with Classroom \\
\hline Teachers & $\begin{array}{l}\text { - Start a video meeting. } \\
\text { - } \text { preate and manage classes, assignments, and grades online without } \\
\text { - Add materials to your assignments, such as YouTube videos, a Google } \\
\text { Forms survey, and other items from Google Drive. } \\
\text { - Give direct, real-time feedback. } \\
\text { - Use the class stream to post announcements and engage students } \\
\text { in question-driven discussions. } \\
\text { - Invite parents and guardians to sign up for email summaries with a } \\
\text { student's upcoming or missing work. }\end{array}$ \\
\hline Students & $\begin{array}{l}\text { - Track classwork and submit assignments. } \\
\text { - Check originality, feedback, and grades. } \\
\text { - Share resources and interact in the class stream or by email. }\end{array}$ \\
\hline Parent/Guardians & $\begin{array}{l}\text { - Get an email summary of your student's work. } \\
\text { - Review announcements and activities. }\end{array}$ \\
\hline Administrators & $\begin{array}{l}\text { - Protect data and set permissions for your users. } \\
\text { - Set up classes and rosters. } \\
\text { - Add or remove students and teachers from classes. } \\
\text { - Get } 24 / 7 \text { support. }\end{array}$ \\
\hline
\end{tabular}

Source: https://support.google.com/edu/classroom/answer/6020279?hl=en\&authuser=0

The following are steps in creating and using Google classroom

1. Open a web browser and go to www.classroom.google.com

The teacher will have to sign in with Google Application for education account.

2. On the welcome screen, click the plus (+) sign at the top and choose create class

3. Type the class name and section in the create class dialogue box.

4. Clicks create, after these procedures a class has been successfully created.

Thereafter the teacher will be given a code which he/she will use to invite students to join the class. Note: The classroom has three main tabs. Below is what the tab means:

Stream: on this tap, the teacher manages class assignments and makes announcements to the participants/students. The teacher can add new assignments, on due dates and attached materials. Upcoming assignments are shown at the left.

Students: This is where the teacher manages theparticipants/students. Here the teacher can invite the participants/students to the classroom from here and manage their permission level. To invite the participants/students to the class, the teacher has to set-up a Google contacts in the Google Apps for Education account or they have to be in the school's directory. 
Google Drive folder: This is where the teacher can add the course title and description, add a location for the class, and add materials to your class.

3. Schoology: through this social site, teachers can manage lessons, engage students, share contents, and connect with other educators.Forteacher, parent/guardian and students to create a new schoology account, they will need to open a mobile browser on their device and go to www.schoology.com then click on sign up bottom and follow the instruction. After signing up then do the following:

1. Go to app.schoology.com

2. Enter your Email and Password. If you cannot remember the email address, check with your instructor or one of your Support Contacts.

3. Click Log in

4. ePals: is an effective and practical way of instructing technology smart students. The website provides digital content to enable self-study as well as a secure learning platform to share work with others all around the world. It also helps teachers to become more confident with using technology and online resources. One of the coolest benefits of the Web is being able to connect with everyone and anywhere (Usman \&Dahiru, 2016). ePals does just that, but focuses on students, helping them to learn language and understand cultures different from their own. To register for ePals for the first time, do the following:

1. Visit https://www.epals.com/\#/connections

2. On the right side bottom of the screen click on sign up

3. Filled all the necessary requirement and click sign up

4. Click on sign in ( provide the logging in details) and click on sign in

5. Skype:Skype is a telecommunications application that specializes in providing video chat and voice calls between computers, tablets, mobile devices, the Xbox One console, and smartwatches over the Internet. Skype also provides instant messaging services. Users may transmit text, video, audio and images (Wikipedia, 2020).Skype can be a great tool for keeping in touch with other educators or even attending educational conferences, seminars and online academic discussion (Usman \& Dahiru, 2016).Even cooler, it can help teacher to connect with other classroom in the form of video conference, even those in other countries. Both students and teachers can have video chatting as a means of enhancing their studies. It is also very helpful in practical demonstration by a master teacher for his students to emulate.

1. In the Skype sign in window, select Create new account (or go directly to the Create an account page).

2. It Will then take you through the process of creating a new account for Skype

6. Grockit: get your students connected with each other in study sessions that take place on this great social site. It offers opportunities across board within and outside the classroom.

1. Visit https://www.courses.com/grockit 
7. Moodle: Community-driven and globally-supported open learning platform. It is used for blended learning, distance education, flipped classroom and other e-learning projects in schools, universities, workplace and other sectors (Costello, 2013). With customizable management features it is used to create private websites with online courses for educators and trainers to achieve learning goals (Gavin cited in Enoidem et al., 2020). Moodle allows for extending and tailoring learning environments using community-sourced plugins. As an e-learning tool moodle has a wide range of standard and innovative features such as a calendar and a grade book (Jordan, 2013). Moodle is a leading virtual learning environment and can be used in many types of environment such as education, training and development and in business settings. Application of Moodle Digital Learning Tool

According to Chris(2018), to use moodle, it requires setting up a site. The teacher will go to https://download.moodle.org/ and download the app. Then follow these tips:

1. Install the "Moodle additional features plugin"

2. Enable push notification

3. Upload a detailed guide of how to use moodle mobile

4. Create a custom theme for your site

5. Enroll all the users in that course via the plugin

\section{Adding Teacher and Students to Moodle}

Before teachers and students are added to moodle they must first have an account on moodle site. Then follow these steps to add them:

1. Log in with administrator account.

2. Go to the course where you want to add teachers and students

3. From the left panel (navigate drawer) click participants

4. Click enroll users Step

5. From the drop down select the users you want and the role you want to give them

6. Click enroll users after this process a fellow teacher and students will be successfully added to a moodle account.

Moreover, Usman and Dahiru (2016) have compiled other digital learning contentswebsites and games related technology tools that can make lessons fun and interesting and more effective:

1. Quora: is used for a wide range of purpose, it can be a great tool for educators. It can be used to connect with other professional or to engage students in discussion after class.

2. Ning: it allows anyone to create a personalized social network, which can be great for both teachers and students alike.

3. Open-Study: encourage your students to work together to learn class material by using a social study site like Open-Study.

4. EduBlogs: it offers a safe and secure place to set up blogs for yourself or your classroom. It is important for developing classroom blogs for tutorials and self-learning.

5. Khan Academic: many teachers use this excellent collection of math, science, and finance lectures and quizzes to supplement their classroom materials. 
6. Manga-High: offer teachers a wealth of resources for game-based learning in mathematics.

7. Fun-Brain: if you are looking for wealth of resources for educational games, look no further Fun-Brain. On it, teachers can take advantage of fun tool for math and reading.

8. Edu-Creation: is an amazing online tool for the iPad that lets teacher (or students) create video-based lesson that teach a given topic. Perfect for studying or getting students to show off their knowledge.

9. Animoto: makes it simple to create video-based lesson or presentation for the classroom and to share them with students or anyone else.

10. Socrative: available for computers, mobile device and tablets, this students' response system engages students through game and exercise on any device they have on hand. Even better, teachers can easily assess students' progress and track grades.

11. Knewton: adaptive learning has been a hot topic in recent months, and with Knewton it is something that any teacher can assess and use. The site personalizes online learning contents for each student according to his or her needs.

12. Kerpoof: on kerpoof, students can become creative with their learning with games, interactive activities, drawing tools and more that are both fun and educational.

13. Study Sync: with a digital library, weekly writing assignments, online writing and peer reviews, common core assignments, and multimedia lessons can be made available. This site is a fully-featured tool for teaching and learning that can be a big help in the classroom.

14. Carrot Sticks: on this site, teachers can take advantage of a wide range of math learning games, giving students practice while they have fun.

\section{CONCLUSION}

Digital learning platform has come to stay especially during COVID-19 pandemic which the entire world is affected in one way or the other. Education sector in Nigeria has to provide training for teachers on how to use various tools in creating digital learning. The teachers will not just wake up to start using these tools without prior training or knowledge. As such, there is need for teacher training. The teachers on their part seeing the trend in teaching which has shifted from traditional to digital method of teaching should utilize various learning tools that could make teaching and learning possible amidst any pandemic.

\section{RECOMMENDATION}

The following recommendations were made:

1 Government at all levels should train teachers to acquire knowledge on how to use various digital learning tools for creating teaching and learning content.

2 Parents should provide their children with necessary items such as items to include but not limited to laptop, smart phone among others that would encourage them to study and learn online.

3 Government through its agencies should focus on how to create avenue for teachers and students to interact and learn outside the traditional classroom.

4 Government through its agencies should make provision for constant electricity supply to avoid disruption during teaching and learning online. 


\section{REFERENCE}

Andreas, S. (2020). The impact of COVID-19 on education. Insight from education at a glance Retrieved on 22 September, 2020 from www.oecd.org/education/education-at-a glance 19991487.htm

Bedford, J., Enria, D., Giesecke, J., Heymann, D.L., Ihekweazu, C., Kobinger, G., \&Ungchusak, K. (2020). COVID-19: towards controlling of a pandemic. The Lancet, 395(10229), $1015-1018$

Chris, R. (2018). Using moodle, account setting up of site. Retrieved on 18th September, 2020 from https://em.m.wikipedia.org/wiki/moodle

Costello, E. (2013). Tool for blended learning, distance education, flipped classroom and other e -learning projects in schools, universities, workplace and other sectors.Retrieved on 12th September, 2020 from https://em.m.wikipedia.org/wiki/googleclassroom.

Enoidem, B, U. Aniedi, D., U. \& Comfort, I., U. (2020). Application of Digital Learning tools for creating teaching and learning contents at COVID-19 pandemic. COVID-19: the pendulum for reconstruction of instructional system in Nigeria 1-16

Jennifer, M. (2020). Study.com/academy/lesson/what-are-online-learning-toolsdefinition-types examples.html\#

Jordan, S. (2013). "E-assessment: past, present and future" New Direction. 9 (1): 87-106.

Kim, J. (2020). Teaching and learning learning covid-19 | inside higher ed. Retrieved from www.insidehighered.com/digital-learning/blogs/learning-innovation/teaching-and learning-after-covid-19

Krieger, K. (2020). Graduate studies and campus closures. Retrieved from https://www.insidehighered.com/advice/2020/03/24/challenges-facing-grad-students-due coronavirusopinion

Linney, S. (2020). How is the spread of the coronavirus impacting higher education institutions? Retrieved from www.qs.com/how-is-the-spread-of-the-coronavirus-impacting-higher education-institutions/

Muhammad, T. Amiya, B. Shafiqul, H. \&Ikram, Ul-Haq (2020).COVID-19 pandemic, outbreak educational sector and student online learning in Saudi Arabia.Journal of Entrepreneurship Education 23(3) 1-14

United Nation (2020). Policy Brief: Education during COVID-19 and Beyond. Retrieved on 20 September, 2020 from www.un.org 
Journal DOI: 10.46654/ij.24889849

Article DOI: 10.46654/ij.24889849.a61128

United Nations Education, Scientific and Cultural Organizations (2020).UNESCO COVID-19 Education Response. Education Section Issue Note Retrieved on 21 September, 2020 fromhttps://en.unesco.org/covid19/educationresponse/issuenotes

Usman, M. \&Dahiru, S. (2016). Rudiments of Micro Teaching and Teaching Practice.A guide to student Teachers.Jos: Ichejum Press

World Health Organization (2020). WHO Recommendations to Reduce risk of Transmission of emerging pathogens from animals to humans in live animal markets. Accessed $13^{\text {th }}$ September, 2020 from https://www.who.int/healthtopics/coronavirus/who recommendations-to-reduce-risk-of-transmission-of-emerging-pathogens-from animalsto-humans-in-live-animal-markets 